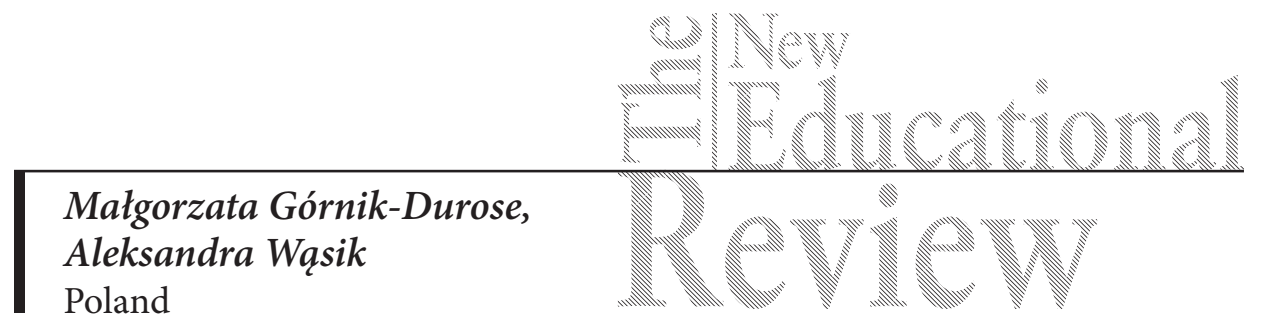

\title{
Market Regulations in Social Relationships and Attitudes Towards Disabled People
}

DOI: $10.15804 /$ tner.2015.40.2.23

\begin{abstract}
The article presents an empirical study on some predictors of attitudes to disabled people. The assumption was that in market-oriented societies attitudes to the needy and underprivileged are connected with the calculation of the costs and benefits of their inclusion in society. Psychological mercantilism is an individual characteristic which makes people especially keen on conducting such calculations. The relation between mercantilism and attitudes to the disabled with the perception of costs and benefits as mediators was examined in the group of 126 university students. The results showed a negative correlation between the main variables as well as the assumed mediation effect.
\end{abstract}

Keywords: attitudes to the disabled, psychological mercantilism, costs and benefits of social inclusion

\section{Introduction}

Members of contemporary societies pay a lot of attention to the physical, intellectual, emotional, and - as a result - social "fitness" of themselves and others. Any sort of disability obviously does not meet this ideal, so it induces an expectation that it should be immediately "repaired" and if it is not possible - marginalized (Wojtyna, Stawiarska, 2013). Despite numerous regulations aiming at ensuring equal rights for people with disabilities and an axiological orientation towards tolerance and integration, feelings of discomfort or even fear during interactions with disabled people are still quite common. In addition, such feelings are supported by misconceptions about the psychological features and social potential of the disabled. Many problems encountered by people with disabilities are generated by inappropriate social attitudes. Positive attitudes can facilitate inclusion and 
acceptance of the disability, whereas negative attitudes can result in exclusion and the transformation of specific functional impairments into generalized personal and social handicaps (Findler, Vilchinsky, Werner, 2007). In order to reduce these problems a comprehensive picture of factors shaping attitudes towards people with disabilities is necessary.

One of the predominant characteristics of contemporary societies is their concentration on the economic aspects of life (Baudrillard, 1970/1998; Bauman, 2009, Barber, 2008, de Graaf, Wann, Naylor, 2005) reflected in the mindsets (mentality) of their members (Sikora, Górnik-Durose, 2013). As Michael Sandel stated in his inspiring book: "The most fateful change that unfolded during the past three decades was [...] the expansion of markets, and of market values, into spheres of life where they don't belong" (Sandel, 2012). It means that market and economic cost - benefit analyses rule domains of human existence that until recently were clearly separated from this kind of regulation.

In social psychology there is a well-established distinction between two types of social relationships - communal and exchange (Clark, Mills, 1993). The communal relationships bring to mind close interactions, such as those between family members, the exchange relationships are more business-like. They are distinguished by principles of giving and receiving benefits. In communal relationships, people take into consideration the welfare of others, benefits are given in response to needs or to demonstrate concern for the other. People do not expect a straight repayment of comparable benefit. In exchange relationships, on the other hand, a benefit is given with the expectation of receiving a comparable benefit in return or in repayment for a benefit received previously. Also Fiske (1992), while listing forms of sociality, locates certain forms of relationships based on market pricing among them. This orients people towards proportionality in ratios and rates to which various aspects of interactions are reduced.

Returning to Sandel (2012) and his analyses, it could be argued that in societies that were shaped by the free market and individualism as a core social value, the exchange and market pricing dominated the way social relationships of all kinds have been created. The domination of market orientations in various domains of human lives reflects also at the individual level. In economics it is shown in the concept of a rational homo economicus - a model of a human being whose behavior is aimed strictly at maximizing his/her utility (benefits of all sorts), in philosophy and psychology - in a concept of mercantile character, described by Fromm (1976/1995).

In such a social and cultural context a question about the position of disadvantaged and needy members of society within systems of welfare rationing has to 
be addressed. Disabled people can be perceived as a cost and burden in societies valuing exchange relationships and market regulations, especially in the case of less affluent societies (van Oorschot, 2006).

\section{Research problem}

In the presented study a problem related to attitudes to the disabled from the perspective of social orientation towards market values has been addressed. The social orientation towards market values was specified at the individual level in terms of psychological mercantilism (Górnik-Durose, 2007), a concept related to traditionally understood materialism (Richins, Dawson, 1992; Belk, 1985), but extending its meaning towards the extrinsic regulation as conceptualized by Deci and Ryan in their self-determination theory (cf. Deci, Ryan, 2000; Kasser, Ryan, 1993, 1996; Ryan, Deci, 2000). Psychological mercantilism is a psycho-behavioral complex of multidimensional nature. It is constructed around extrinsic values such as money and material possessions, image and fame (cf. Kasser, Ryan, 1993, 1996) and accompanied by a perception of the world as a zero-sum game, with "social Darwinism" as a ruling principle (cf. Duckitt, Fisher, 2003; Skarżyńska, Radkiewicz); decision criteria used by people in relation to their everyday activity are based on a "cost-benefit analysis" and tend to secure mainly material gains, and a style of self-presentation involves an exposition of the socially approved signs of material success, physical attractiveness and social recognition.

If people are asked about their attitude to the disabled and at the same time confronted with information related to the economic aspects of social inclusion of this group their attitudes could vary. People presenting a high level of the abovementioned psychological mercantilism should be more sensitive to economic information and that might negatively influence their attitudes towards disadvantaged members of society. Such an assumption is based on the data showing that people with extrinsic orientation have a lower level of empathy and are unwilling to engage in any sort of pro-social activities (Kasser, Cohn, Ryan, Kanner 2007). They are also prone to prejudice, tend to accept social inequalities and prefer hierarchical relationships (Duriez, 2011; Duriez, Vansteenkiste, Soenens and De Witte 2007). In addition, materialism correlates positively with racism (Roets, van Hiel, Cornelis, 2006), which may suggest a lack of acceptance of any sort of social diversity.

In their empirical analysis of materialism and racism, Roets, van Hiel and Cornelis (2006) showed also a mediating effect of self-interest on the relation 
between these two variables. It means that the belief that support given to ethnic minorities collides with personal welfare increases even more racism in materialistic people. It could be expected then that such an effect will appear also in the context of other deserving social groups, e.g. the disabled. Thus, the attitudes towards the disabled might be at least less positive if people were to perceive social actions from which the disabled benefit as being in conflict with their own potential outcomes.

However, Roets et al. took into consideration only a situation when self-interest was connected with protecting themselves against potential loss. There is, though, the other side of the coin - the welfare actions towards one group of people could also bring benefits for others. In this situation self-interest is connected with potential gains, not losses. This way of thinking is supported by prospect theory, a seminal theoretical framework proposed by Kahneman and Tversky (1979), which has been applied by psychologists and even economists to explain various aspects of human behavior over the decades. From the point of view of the prospect theory, which states that losses and gains have non-equal utility and the subjective weight of loss is more substantial that the weight of gain, it could be argued that the perception of costs connected with the social inclusion of the disabled will be more important for attitudes to them than perceptions of gains. There should be, then, a negative relation between attitudes towards the disabled and the perception of costs of their inclusion and a relatively weaker positive relation between these attitudes and the perception of benefits. These effects should become more and more prominent with increasing mercantilism and in the case of self-interest as opposed to social interest, understood in terms of cost and benefits for the whole society.

To summarize, in the presented study the following hypotheses were verified:

1. There is a negative correlation between psychological mercantilism and attitudes towards disabled people.

2. Perception of potential gains connected with social inclusion of the disabled will increase positive attitudes towards them, whereas perception of potential costs of the inclusion will weaken these attitudes.

3. Perception of costs and benefits in relation to self-interest versus social interest significantly mediates the relation between psychological mercantilism and the attitudes towards disabled people. 


\section{Method}

\section{Subjects}

The data was collected from 126 students from Silesian universities, of whom 73 were women and 53 men, aged $18-25.42 .1 \%$ of the subjects had previously had some sort of contact with disabled people from the group to which the research materials were related.

\section{Instrument and Procedures}

At the beginning the subjects were asked to complete the Questionnaire of World Beliefs created by the first author to measure psychological mercantilism (Górnik-Durose, 2007, 2013). The questionnaire consists of three parts related to the theoretical aspects of the construct, which are: (a) world beliefs, i.e. opinions about the way the world is organized (e.g. "There is a wide-spread belief in today's world that if you do not have money and appearance you are nobody"), (b) the character of social relations, i.e. personal beliefs about principles underlying human behavior (e.g. "Friendship is OK, but it is useful to have influential acquaintances"), (c) preferences concerning self-presentation (an assessment of people who "Talk mainly about costs of everything and what is worth or not spending money on"). The core aspect of psychological mercantilism is the character of personal relations with the world. Each part of the questionnaire contains a pair of 4-item subscales. One subscale from each pair describes mercantile mentality and behaviors, the other - its contradiction. The subjects were asked to mark their answers on a 7-point scale ranging from 1 (definitely not/negative) to 7 (definitely yes/ positive).The scores for each aspect were calculated as the difference between sums derived from mercantile and non-mercantile items. The internal consistencies of all the 4 -item subscales, indicated by Cronbach's alpha, varied from 0.61 to 0.73 in the presented study.

After completing the questionnaire, the subjects were presented with a short description of the situation of people with intellectual disability and some aspects of their inclusion in Polish society. There were five versions of the descriptions (cf. Wąsik, 2014). The first (basic) version included only facts about the population of the disabled and about some inclusion efforts undertaken. The remaining four descriptions included additional notes related to: (a) benefits of inclusion for an individual (self-interest/benefits), (b) benefits of inclusion for society (social interest/benefits), (c) costs of inclusion for an individual (self-interest/costs), and (d) costs of inclusion for society (social interest/costs). The descriptions were assigned randomly to the subjects. After reading one of the descriptions, all the subjects 
were asked to complete a questionnaire which measured their attitudes towards the disabled and answer the following questions:

(a) In your opinion, do attempts to integrate people with intellectual disabilities into society bring significant benefits for that society?

(b) In your opinion, are attempts to integrate people with intellectual disabilities connected with significant social costs?

(c) Do you see any personal benefits from the integration of intellectually disabled people?

(d) Do you think that you personally pay any costs or lose something because of these integration attempts?

The subjects placed their answers on the scale from 1 (definitely not) to 6 (definitely yes).

The attitudes towards people with disabilities were measured with the Attitudes Towards Disabled People Scale created by Sękowski (1994). The scale consists of 30 items, which relate to various attitudes to the disabled, but build one strong factor. The higher score in the scale the more positive the attitudes are. The internal consistency of the scale indicated by Cronbach's alpha was 0.88 in the presented study. The subjects gave answers on the scale ranging from -3 (I strongly disagree) to +3 (I strongly agree).

\section{Data Analysis}

Data analysis included examination of zero-order correlations between variables and mediation analysis based on the approach proposed by Preacher and Hayes (2008), applied in order to test multiple mediator models with a bootstrapping technique. All statistical analyses were conducted in IBM SPSS 22 and PROCESS for SPSS by Hayes (http://www.afhayes.com).

\section{Results}

\section{Attitudes to the disabled, perception of costs and benefits of inclusion and psychological mercantilism}

The first step of data analysis was to check zero-order correlations between three aspects of mercantilism and attitudes to the disabled. Only the Social Relations aspect correlated significantly with attitudes to the disabled $(r=-0.22, p<0.05)$ as well as with the perception of costs and benefits of their inclusion $(r=0.24, p<0.01$ for self-interest/cost, $r=-0.32, p<0.01$ for self-interest/benefits, $r=-0.23, p<0.01$ for social interest/benefits, no significant correlation was found for social inter- 
est/costs). However, Social Relations is the core aspect which defines the whole construct, so it may be stated that there was a relationship between mercantilism and the examined attitudes. The correlations were relatively weak, but statistically significant. They showed the assumed relation: the stronger psychological mercantilism was the less positive the attitudes to the disabled were. That result confirmed the first hypothesis. In addition, mercantilism appeared to be connected with the perception of costs and benefits of the social integration of the disabled. The stronger it was the more costly the inclusion was perceived to be from the self-interest point of view and fewer benefits were perceived in both social and individual aspects.

At this point it has to be remembered that in order to enhance concentration on the issue of social inclusion of the disabled the subjects were faced with different kinds of description, which included information about the social and individual costs and benefits of the inclusion. It was expected that the descriptions would differentiate attitudes, however, it was not the case. There were no significant differences in attitudes between the groups of subjects who had read different texts and even more - the answers to the questions related to the cost-benefit assessment did not differ significantly across the groups. It means that the evaluation of costs and benefits of the social inclusion of disabled people was not situational, but deeply rooted in the beliefs and attitudes of the subjects.

The correlation coefficients indicating relations between the attitudes and perception of costs and benefits were also significant $(r=0.40, p<0.01$ for social interest/benefits, $r=0.44, p<0.01$ for self-interest/benefits, $r=-0.42, p<0.01$ for social interest/costs and $\mathrm{r}=-0.19, \mathrm{p}<0.05$ for self-interest/costs). They confirmed the second hypothesis - perception of potential gains connected with the social inclusion of the disabled was associated with more positive attitudes towards them, whereas the perception of potential costs of the inclusion significantly weakened these attitudes.

\section{Mediating effect of perception of costs and benefits on the relation between psychological mercantilism and attitudes to the disabled}

As shown before, psychological mercantilism in its core aspect related to the character of social relations was significantly correlated with attitudes to the disabled, as well as with the perception of the costs and benefits of their social inclusion. On the other hand, attitudes to the disabled were also connected with the perception of the costs and benefits of inclusion. Such a configuration suggests that the perception of costs and benefits might be the major factor explaining the attitudes to the disabled in mercantile people. The basic assumption related to the 
nature of mercantilism is that the construct is founded on the calculation of losses and gains (Górnik-Durose, 2007). Thus, the perception of costs and benefits should be a significant mediator of the relationship between mercantilism and attitudes.

Figure 1 shows the model and Table 1 shows the results of mediation analysis, which was conducted according to the method of assessing indirect effects in multiple mediator models proposed by Preacher and Hayes (2008). The bootstrapping technique for multiple mediator models allows for the estimation of indirect effects for several mediators. The analysis was conducted twice. First, all the four indicators of the perception of costs and benefits from personal and social perspectives were included as mediators, second - the indicators of the combined assessment of costs and benefits were taken into consideration (social interest/ costs + self-interest/costs and social interests/benefits + self-interest/benefits).

Figure 1. A hypothetical model of the relation between psychological mercantilism and attitudes to the disabled mediated by the perception of the costs and benefits of their inclusion

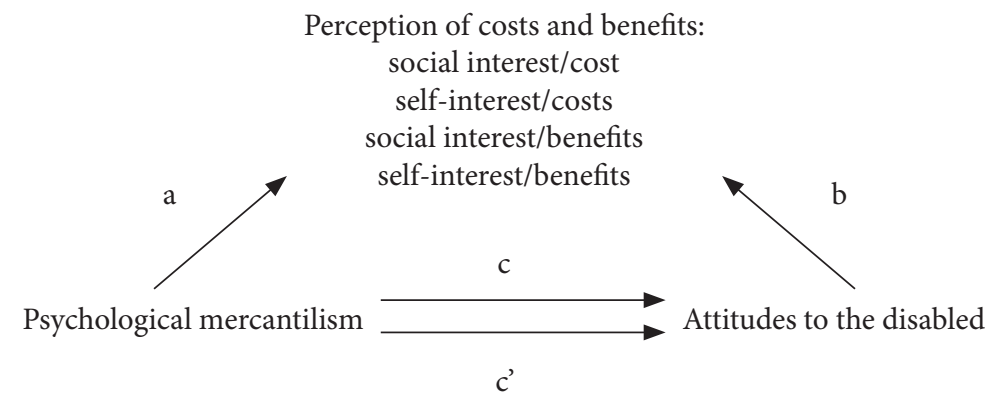

The results show the mediating effect of the perception of the costs and benefits of social inclusion of disabled people from the social and personal perspectives on the relation between mercantilism and attitudes to the disabled. The regression coefficients (c') were reduced in comparison to $c$, when the perception of costs or benefits was controlled, both in their four forms and as combined indicators of costs and benefits.

As Table 1 shows, the total indirect effect of mercantilism on the attitudes to the disabled through all the four types of costs/benefits assessments was significant, the examination of the specific effects revealed, however, that only the effect of the perception of benefits from the self-interest perspective was significant. Confidence intervals for the effects of the perception of costs and perception of benefits 
Table 1. Estimates in the tested models of relations between psychological mercantilism and attitudes to the disabled mediated by the perception of costs and benefits

\begin{tabular}{|c|c|c|c|c|c|c|c|c|}
\hline \multirow{3}{*}{$\begin{array}{c}\text { Mediators } \\
\text { Social interest/costs }\end{array}$} & \multirow{3}{*}{$\begin{array}{c}\mathrm{a} \\
0.14 \\
\end{array}$} & \multirow{3}{*}{$\begin{array}{c}\mathbf{b} \\
-0.24^{*}\end{array}$} & \multirow[t]{2}{*}{ c } & \multirow[t]{2}{*}{$c^{\prime}$} & \multicolumn{4}{|c|}{$\begin{array}{c}\text { Bootstrap results } \\
\text { (5000 bootstrap resamples) }\end{array}$} \\
\hline & & & & & \multirow{2}{*}{$\begin{array}{l}\text { Estimate } \\
-0.03\end{array}$} & \multirow{2}{*}{$\begin{array}{r}\text { SE } \\
0.03\end{array}$} & \multicolumn{2}{|c|}{$95 \% \mathrm{CI}$} \\
\hline & & & \multirow{6}{*}{$-0.22^{\star}$} & \multirow{4}{*}{-0.06} & & & -0.12 & 0.00 \\
\hline Self-interest/costs & $0.24^{* *}$ & 0.06 & & & -0.00 & 0.03 & -0.04 & 0.07 \\
\hline Social interest/benefits & $-0.23^{\star *}$ & $0.19^{*}$ & & & -0.04 & 0.03 & -0.15 & 0.00 \\
\hline Self-interest/benefits & $-0.32^{\star \star}$ & $0.24^{\star \star}$ & & & -0.08 & 0.04 & -0.18 & -0.01 \\
\hline COSTS & 0.15 & -0.11 & & \multirow{2}{*}{-0.06} & -0.02 & 0.02 & -0.09 ; & 0.01 \\
\hline BENEFITS & $-0.33^{\star *}$ & $0.44^{\star *}$ & & & -0.14 & 0.05 & -0.28 & -0.06 \\
\hline TOTAL & & & & & -0.15 & 0.06 & -0.29 ; & -0.07 \\
\hline
\end{tabular}

Note: ${ }^{*} \mathrm{p}<0.05 ; \quad{ }^{*} \mathrm{p}<0.01 ; \quad \mathrm{a}, \mathrm{b}, \mathrm{c}, \mathrm{c}^{\prime}-$ unstandardized regression coefficients

from the social point of view included zero that suggested a non-significant mediation.

The analysis of the combined costs and combined benefits perceptions showed clearly that although the total indirect effect of mercantilism on the attitudes towards the disabled through combined costs and benefits was significant, only the effect of benefits was responsible for it. The confidence interval for costs included zero. As expected in such a situation, the contrast between mediators was also significant ( $95 \%$ confidence interval of 0.04 to 0.28 ; point estimate of 0.13 ). It means that the negative attitudes to the disabled associated with psychological mercantilism are due mostly to reluctance to perceive benefits and advantages of the social inclusion of this group.

\section{Discussion}

The results show that if an economic perspective is involved in thinking about the problems of disabled people a "cost-benefit analysis" could influence attitudes towards them. The more mercantile people are, the less positive attitudes they show towards the disadvantaged members of their society. These findings correspond with the results showing that people who are extrinsically oriented (as mercantile individuals) are less empathic, not keen on pro-social activities (Kasser, Cohn, Ryan, Kanner 2007) and prone to prejudice (Duriez, 2011; Duriez, Vansteenkiste, 
Soenens and De Witte 2007; Roets, van Hiel, Cornelis, 2006). The link between mercantilism and attitudes to the disabled seems to be founded on the reluctance to admit that there could be benefits or advantages from the social inclusion of disabled people in society.

There are two results of the study which need to be explained. The first is that mercantilism was connected with attitudes towards the disabled only in one of its three aspects. The way people see rules underlying social life (World Beliefs) and the way people tend to present themselves (Self-Presentation) did not relate to these attitudes. Only the core aspect (Social Relations) - reflecting personally approved principles on which an individual's behavior is founded - appeared to shape the attitudes to the disabled. Mercantile world beliefs could result in both compassion and the understanding of difficulties disabled people encounter in the world ruled by social Darwinism or its opposite - rejection of the disabled who do not fit in such reality. Mercantile self-presentation could also go in both directions - towards rejection of the weak and needy or towards a calculated expression of empathy intended to create a desirable social image (Kasser, Ryan, 1993, 1996; Sandel, 2012). Only core personal beliefs when mercantile could lead directly to the negative reactions towards the underprivileged and potentially less effective members of society.

The second result which needs to be explained shows the dominant effect of the perception of a lack of benefits connected with the social inclusion of the disabled, especially in connection with self-interest. As assumed on the basis of prospect theory (Kahneman, Tversy, 1979), a perspective of losses is more important for people than a perspective of gains. "Pains" caused by loss hurt more than the "joys" of gains please. Thus, it would be expected that the perception of costs would shape attitudes more than the perception of a lack of benefits. However, it could be argued that a lack of potential gains is a loss, thus the results fit into the framework of prospect theory. Also, it is possible that psychological mercantilism is a feature which makes people more responsive to gains than losses, and a lack of benefits is experienced by them as more disappointing than could be expected. This assumption must be verified in future research.

\section{Conclusions}

The main conclusions from the study are as follows:

1. Individual expression of the societal market orientation in the form of psychological mercantilism is connected with a lack of support and understanding for the problems of disabled people. 
2. This is based mainly on an unwillingness to acknowledge potential benefits of the inclusion of such people in society.

These conclusions may be important from the point of view of actions taken in order to integrate disabled people into other members of society. In the face of the above-mentioned market orientation of contemporary societies (cf. Baudrillard, 1970/1998, Bauman, 2009, Barber, 2008, de Graaf, Wann, Naylor, 2005, Kasser, Cohn, Ryan and Kanner 2007; Sandel, 2012) and a dominant "body and mind perfect" ideal (Dittmar, 2008; Sikora, Górnik-Durose, 2013; Wojtyna, Stawiarska, 2013), attempts to integrate people who are "different" may be a big challenge. If psychological mercantilism as an expression of this orientation at the individual level is an important component of the contemporary mindset, the only way to promote acceptance for diversity and positive attitudes towards people with disabilities is to stress any sort of gains - for society as a whole as well as for individuals within this society - connected with inclusion. The economic messages could be effective for the economically oriented mind, however, other kinds of advantages should be also presented. They may be effective especially when positioned within a self-interest frame.

\section{References}

Baudrillard, J. (1970/1998). The Consumer society. Myths \& Structures. London: SAGE Publications.

Barber, B.R. (2008). Skonsumowani. Jak rynek psuje dzieci, infantylizuje dorostych i polyka obywateli. Warszawa: Warszawskie Wydawnictwo Literackie MUZA SA.

Bauman, Z. (2009). Konsumowanie życia. Kraków: Wydawnictwo UJ.

Belk, R.W. (1985). Materialism: Trait Aspects of Living in the Material World. Journal of Consumer Research, 12, 265-280.

Clark, M.S., \& Mills, J. (1993). The difference between communal and exchange relationships: What it is and what it is not. Personality and Social Psychology Bulletin, 19, 684-691.

Graaf de, J., Wann, D., \& Naylor, T.H. (2005). Affluenza. The All-Consuming Epidemic. San Francisco: Berrett-Koehler Publishers, Inc.

Deci, E.L., \& Ryan, R.M. (2000). The "what" and "why" of goal pursuits: Human needs and the self-determination of behavior. Psychological Inquiry, 11, 227-268.

Dittmar, H. (Ed.) (2008). Consumer Culture, Identity and Well-Being. The Search for the 'Good Life' and the 'Body Perfect'. Hove and New York: Psychology Press.

Duckitt, J., \& Fisher, K. (2003). Social threat, worldview, and ideological attitudes. Political Psychology, 2, 63-84.

Duriez, B. (2011). The social costs of extrinsic relative to intrinsic goal pursuits revisited: 
The moderating role of general causality orientation. Personality and Individual Differences, 50, 684-687.

Duriez, B., Soenens, B., \& Vansteenkiste, M. (2007). In search of the antecedents of adolescent authoritarianism: The relative contribution of parental goal promotion and parenting style dimensions. European Journal of Personality, 21, 507-527.

Findler, L., Vilchinsky, N., \& Werner, S. (2007). The Multidimensional Attitudes ScaleToward Persons With Disabilities (MAS): Construction and Validation. Rehabilitation Counseling Bulletin 50, 166-176.

Fiske, A.P.(1992). The Four Elementary Forms of Sociality: Framework for Inified Theory of Social Relations. Psychological Review, 99 (4), 689-723.

Fromm, E. (1976/1995). Mieć czy być? Poznań: Dom Wydawniczy Rebis

Górnik-Durose, M. (2007). Nowe oblicze materializmu, czyli z deszczu pod rynnę. Psychologia. Edukacja i Społeczeństwo, 4, 211-226.

Górnik-Durose, M. (2013). Kwestionariusz Przekonań o Świecie - klucz. Materiały niepublikowane.

Kahneman, D., \& Tversky, A. (1979). Prospect theory: An analysis of decision under risk. Econometrica, 47, 263-291.

Kasser, T., Cohn, S., Kanner, A.D., \& Ryan, R.M. (2007). Some Costs of American Corporate Capitalism: A Psychological Exploration of Value and Goal Conflict. Psychological Inquiry, 18, 1-22.

Kasser, T., \& Ryan, R.M. (1993). A dark side of the American dream: correlates of financial success as a central life aspiration. Journal of Personality and Social Psychology, 65 (2), $410-422$.

Kasser, T., \& Ryan, R.M. (1996). Further examining the American dream: Differential correlates of intrinsic and extrinsic goals. Personality and Social Psychology Bulletin, 22, 280-287.

Preacher, K.J., \& Hayes, A.F. (2008). Asymptotic and resampling strategies for assessing and comparing indirect effects in multiple mediator models. Behavior Research Methods, 40, 879-891.

Richins M.L., \& Dawson S. (1992). A Consumer Values Orientation for Materialism and Its Measurement: Scale Development and Validation. Journal of Consumer Research, 19, 303-316.

Roets, A., van Hiel, A., \& Cornelis, I. (2006). Does Materialism Predict Racism? Materialism as a Distinctive Social Attitude and a Predictor of Prejudice. European Journal of Personality, 20, 155-168.

Ryan, R.M., \& Deci, E.L. (2000). Self-determination theory and the facilitation of intrinsic motivation, social development, and well-being. American Psychologist, 55, 68-78.

Sandel, M. (2012). What money Can't Buy: The Moral Limits of Markets. Penguin Book. Kindle Edition.

Sękowski, A. (1994). Wybrane koncepcje teoretyczne postaw wobec osób niepełnosprawnych. In: M. Chodkowska (Ed.), Człowiek niepetnosprawny (pp.97-109). Lublin: Wydawnictwo Uniwersytetu Marii Curie-Skłodowskiej. 
Sikora, T., \& Górnik-Durose, M. (2013). O mentalności współczesnego człowieka, jej źródłach i przejawach. In: M.Górnik-Durose (Ed.) Kultura współczesna a zdrowie. Aspekty psychologiczne (pp. 15-50). Sopot: GWP.

Skarżyńska, K., \& Radkiewicz, P. (2011). Co wzmacnia/osłabia społeczny darwinizm? O roli doświadczeń z ludźmi, osobowości, wartości osobistych i przywiązania do wspolnoty. Psychologia Społeczna, 6, 7-23.

Van Oorschot, W. (2006). Making the difference in social Europe: deservingness perceptions among citizens of European welfare states. Journal of European Social Policy, 16 (1), 23-42. DOI: 10.1177/0958928706059829

Wąsik, A. (2014). Merkantylizm psychiczny a postawy wobec osób niepetnosprawnych intelektualnie. Unpublished Master's thesis. Faculty of Pedagogy and Psychology. University of Silesia in Katowice.

Wojtyna, E., \& Stawiarska, P. (2013). O współczesnym rozumieniu zdrowia. In: M.GórnikDurose (Ed.) Kultura współczesna a zdrowie. Aspekty psychologiczne (pp. 51-76). Sopot: GWP. 